\title{
Research on the Choice of Enterprise Value Investing Under the New Environment -Case Study
}

\author{
Liyao $^{1, *, \dagger}$, Jiaxin Wang ${ }^{2, \dagger}$, Wanyue $\mathrm{He}^{3, \dagger}$ \\ ${ }^{1}$ Rutgers Newark College, Northeast Normal University, Changchun, 130117, China \\ ${ }^{2}$ International business faculty, Beijing Normal University, Zhuhai, 519087, China \\ ${ }^{3}$ School of Economics and Management, Anhui University of Science and Technology, Huainan, 232000, China \\ *Corresponding author. Email: liy488@nenu.edu.cn \\ ${ }^{\dagger}$ All these authors contributed equally.
}

\begin{abstract}
In order to provide reference indexes for investors when they use value investing to make investment decisions and assist companies to recognize the aspects, they should pay attention to in operation. We use the method of quantitative analysis in profitability, risk and market respectively to make value investment decisions among three leading enterprises in different industries. In the profitability analysis, we use return on assets and return on equity. Through the analysis in this aspect, we draw a conclusion that JD is the best choice. Since the return on equity includes return on assets and Leverage ratio, Apple and JD are more successful in generating profit internally. But the high return on equity of Apple is probably attributed to relying heavily on the debt to generate a higher net profit. In the risk analysis, we analysed and compared the companies' quick ratio, current ratio and debt-to-equity ratio. JD would be optimal which is a well-capitalized company with high long-term debt repayment ability and minimal investment risk. In the market analysis, three indexes including earnings per share, the price-to-earnings ratio and the price-to-book ratio are chosen. We consider JD would be the best with a good price-to-book ratio and the highest price-to-earnings ratio which stands for huge development potential. Through this paper, we provide a theoretical basis for value investing and derivation. Besides, we also offer investors the experience which can assist them to make investment decisions.
\end{abstract}

Keywords: Value investing, Quantitative analysis, Jingdong, Apple, Qualcomm.

\section{INTRODUCTION}

Value investing uses fundamental analysis to analyse the value of companies' $s$ stocks to see whether some stocks' s value has been underestimated. Through this investing strategy, we can predict the variation trend of the stock price in the future and it can show the stocks' $\mathrm{s}$ real value to a large degree. Therefore, for investors, value investing avoids blindness in investment so that they can discover more stocks which are worth being invested in and decline investing risk at the same time. From 2020 to this day, the world economy has been walloped by the epidemic situation of coronavirus so the stock market quotation was not very positive for a long time. Under the circumstances, investors paid much attention to the impact of the virus on the companies and predict their future with the spread and changes of the epidemic. For example, online education became popular in this situation which could avoid the spread of the virus to a large degree and the stock price raised obviously. But with the effective control of the epidemic, the recovery of offline teaching will make the heat of this industry decline. To get benefits in the long run, they not only pursue high profits in a short period but also focus on the long-term development of companies. Thus, value investing plays a more and more significant role.

The theory of value investment started late in China. Enterprise Value Appraisal and Value Growth, written by $\mathrm{Li} \mathrm{Lin}$ and $\mathrm{Li} \mathrm{Ji}$ in 2001, is the first book that systematically discusses the enterprise value appraisal in China. This book points out the applicability and limitations of each common enterprise value appraisal method [1]. Wang Guoping showed that the PB method and PE method are the basic valuation methods of Ashares, and it is necessary to make A comprehensive 
evaluation according to different industries and companies to supplement other valuation methods [2]. As early as 20 years ago, China Securities Journal selected financial indicators such as return on assets, current ratio, and liability ratio to reflect the operating conditions of listed companies.

In the later period, domestic researchers added more factors of the domestic market and industry conditions into the analysis to enrich the research results. Zou Xiongfei uses the indicators of profitability, operation ability, debt-paying ability, development ability, and equity expansion ability, and uses the technology of factor analysis to construct the investment value evaluation system of listed industrial automation companies. The factor calculation results of 61 listed industrial automation companies are obtained, which confirm the feasibility of business automation industry evaluation and expand the application industries of previous empirical research methods [3]. Zhang Mingming constructed a value evaluation system for the emerging integrated circuit industry from the six indicators of profitability, growth, solvency, cash flow, asset management, and equity expansion. At the same time, he also added non-financial indicators to it, which proved the importance of non-financial indicators in value evaluation and proposed a new direction for value evaluation [4].

From an international point of view, pioneering authors like Graham and Dodd, Fisher and Fama and French developed different approaches to value investing in different time periods and different economic-financial contexts. Scholars use quantitative analysis by focusing on a balance sheet, income statements and cash flow to look into the area of value investing. They illustrated that it is the foundation to do value investing from an entrepreneurial view by coming up with a concept of 'margin of safety'. To ensure a sufficient safety margin, the earnings/price ratio should be equal to the effective rate of high-grade bonds [5-6]. Other scholars added that 'value stock' which is evaluated by price to book value, price to earnings, price to cash flow, dividend to price ratio has higher returns than 'glamour stocks'[7-8]. In recent days, many studies stated that value investing is generally unprofitable for almost 30 years and purchasing stock according to value investing is just identifying companies with temporarily inflated accounting numbers [9-10]. However, expectations of fundamental information have been and continue to be an important driver of security returns. There is little empirical evidence of theoretical foundation to support the criticisms. Some financial institutions with unusual improvement in the performance and valuation and nonfinancial value firms like retail, oil companies are the hope of value investing [10-11].

In conclusion, after studying the theory of value investment at home and abroad, we discover that compared with the abundant theoretical results of foreign research on investment value, domestic research on investment value is more inclined to practical evaluation. It is a lack of research on the theory of value investment and application on the micro-level. In this paper, we use value investment as a research perspective and choose QUALCOMM, Apple and JD as the objective of the study. We pay most attention to the companies' investment and analysis on the micro-level. The conclusion of this paper provides the expansion of theoretical research for the value investment on the one hand and offers enterprises and individual investors practice reference.

\section{DATA AND METHOD}

\subsection{Data}

The paper collects data from Investing [12], Macrotrends [13] and Readyratios [14]. We choose three companies as study objects, which are JD, Apple and Qualcomm. The data content includes financial data and stock data from 2017 to 2020 . Financial data includes total asset, total equity, net income, preferred dividend, long-term liability, current liability, current asset, inventory, the number of share outstanding, the number of preferred shares, earnings, average ROE and of the industry level. Stock data includes the opening price, the closing price.

\subsection{Method}

ROA is a financial ratio which shows how the company makes profits by using its assets. Managers and investors can make use of ROA to evaluate how efficient a company's management is at using its assets to generate earnings. A study found the relationship between net income, total assets and ROA [15].

$$
\text { Return on asset }(R O A)=\frac{\text { Net income }}{\text { Total assets }}
$$

ROA indicates dollars the company earns per unit of asset. When the efficiency of making profits is higher, the company generates more money per unit of asset. By comparing the ROA of different companies, managers and investors know the performance of target companies. In one industry, we can distinguish the type of companies according to ROA ratio. When the net income is equal, companies with more assets have lower ROA while companies that rely less on assets have higher ROA.

$\mathrm{ROE}$ is a ratio to measure financial performance. It evaluates the profitability of a corporation in relation to stockholder's equity. The study also showed the equation of ROE [15].

$$
\text { Return on equity }(R O E)=\frac{\text { Net income }}{\text { Total equity }}
$$


The ratio indicates the dollars the company generates per unit of equity. ROE is a more comprehensive ratio than ROA and it includes the effects of leverage. In DuPont analysis, ROE can be divided into two parts [15]. $R O E=R O A \times$ Equity multiplier $=R O A \times\left(1+\frac{\text { Debt }}{\text { Equity }}\right)$

We can know which factors contribute most to ROE by evaluating each part. When we compare two similar corporations, we can analyse the ROE of each company and find the reasons. If ROE is too low, we can infer that creditors consider the company as riskier and require higher interest. Or the company relies less on leverage to generate income. Identifying the reasons helps us to appropriately evaluate a company.

$$
\text { Current ratio }=\frac{\text { Current asset }}{\text { Current liabilities }}
$$

The current ratio is the ratio of current assets to current liabilities, and the calculation formula of the current ratio is mentioned in "brief talk about the current ratio index" by Zhang Baoqing. More specifically, it is the ratio of assets that can be turned into cash within a year or an operating cycle to liabilities during this period [16]. The higher the current ratio is, the stronger the liquidity ability of the enterprise's assets is, and the higher the short-term debt repayment level is. Not only does the debt repayment ability of an enterprise relate to the overall operation of the enterprise, but also relates to the reputation.

$$
\text { Quick ratio }=\frac{\text { Current asset-Inventory }}{\text { Current liabilities }}
$$

This formula is the index of enterprise solvency mentioned by Hui Ruiling. Compared with the current ratio, the quick ratio is the supplement of the current ratio. The quick ratio represents the ability to pay off current liabilities by immediately turning assets into cash. It can more directly reflect the short-term solvency of enterprises because the quick asset deducts some parts that are hard to turn into cash from current assets. The result of a standard quick ratio is usually 1 .

$$
\begin{gathered}
\text { Long term debt }- \text { to }- \text { equity ratio }= \\
\frac{\text { Long term liability }}{\text { Total equity }}
\end{gathered}
$$

Long term debt equity ratio is also one of the indicators of enterprise debt paying ability mentioned by Hui Ruiling [17]. It is used to analyse the long-term debt paying ability of enterprises. The ratio reflects the degree to which the owners of an enterprise protect the rights and interests of creditors. The smaller the ratio, the stronger the solvency of the enterprise.

Earnings per share (EPS) is the net profit or the net loss which the shareholders can get per common share [18].

$$
\text { Earnings per share }=\frac{\text { Net income }}{\text { Total equity }}
$$

The price-to-earnings ratio, or $\mathrm{P} / \mathrm{E}$ ratio, is the money the investors would like to pay for the unit income statement [19].

PE-TTM refers to the PE ratio within a certain period (generally 12 recent consecutive month2 or 4 recent consecutive financial quarters)[20].

$$
P E-T T M=\frac{\text { The market price per common share }}{\text { Earning per common share }}
$$

Earnings per Share

$=\frac{\text { the net income of the company in the past } 12 \text { months }}{\text { Total number of shares sold on issue }}$

The price-to-book ratio, or $\mathrm{P} / \mathrm{B}$ ratio, is a financial ratio used to compare a company's current market price to its book value [22].

$$
P B=\frac{\text { The market price per share }}{\text { Net assets per share }}
$$

\section{RESULTS AND DISCUSSION}

The paper focuses on value investing as the main research point and analyzes three companies from profitability, risk and market aspects. In the profitability analysis, we use ROA and ROE ratios; in risk analysis, we choose the current ratio, cash ratio and long-term debt-to-equity ratio; in market analysis, we use EPS, PETTM and PB ratios. The analysis is followed.

\subsection{Profitability Analysis}

In terms of profitability analysis, we choose ROA and ROE to analyze three companies. According to the data provided from Investing website, we summarize the average ROE and ROA of the companies from 2017 to 2020. See table 1 and table 2.

Table 1. Net income, total assets and total equity of the companies from 2017 to 2020

\begin{tabular}{|c|c|c|c|c|c|}
\hline years & 2017 & 2018 & 2019 & 2020 & Average \\
\hline Net income & & & & & \\
\hline JD & 152.26 & 2491.63 & 12184.16 & 49405.22 & 14736.37 \\
\hline Apple & 48351 & 59531 & 55256 & 57411 & 55137.25 \\
\hline
\end{tabular}




\begin{tabular}{|c|c|c|c|c|c|}
\hline Qualcomm & 2445 & 4964 & 4386 & 5198 & 1766.25 \\
\hline Total assets & & & & & \\
\hline JD & 184054.97 & 209164.86 & 259723.7 & 422287.79 & 268807.8 \\
\hline Apple & 375319 & 365725 & 338516 & 3233888 & 1078362 \\
\hline Qualcomm & 65486 & 32718 & 32957 & 35594 & 41688.75 \\
\hline Total equity & & & & & \\
\hline JD & 52040.81 & 59770.97 & 81855.97 & 187543.3 & 95302.76 \\
\hline Apple & 134047 & 107147 & 90488 & 65339 & 99255.25 \\
\hline Qualcomm & 30746 & 807 & 4909 & 6077 & 10634.75 \\
\hline
\end{tabular}

*in billions of USD

Data source: www.investing.com

ROA is one of the ratios which measure the profitability of a business in relation to its total assets. It shows how well the business gets profits from the capital generated. From the table, we know that the ROA of Apple company is the highest while JD ranks last among three companies. It is obvious that Apple is more efficient in making a profit compared with the other two companies. However, when compared with the industry average level, ROA of JD is higher than industry level. From companies like Qualcomm and Apple, they require expensive property, plant and equipment to generate income as opposed to companies in other two industries. JD does not require a lot of assets to operate. Therefore, Qualcomm and Apple would naturally have a lower ROA.

Table 2. ROE and ROA of the companies

\begin{tabular}{|c|c|c|c|c|}
\hline \multirow{2}{*}{$\begin{array}{c}\text { Ratio } \\
\text { company }\end{array}$} & \multicolumn{2}{|c|}{ ROE 5YA } & \multicolumn{2}{c|}{ ROA 5YA } \\
\cline { 2 - 5 } & company & industry & company & industry \\
\hline Qualcomm & $16.61 \%$ & $29.44 \%$ & $4.24 \%$ & $17.19 \%$ \\
\hline Apple & $55.55 \%$ & $39.44 \%$ & $5.11 \%$ & $17.19 \%$ \\
\hline JD & $15 \%$ & $2.45 \%$ & $5.48 \%$ & $0.98 \%$ \\
\hline
\end{tabular}

Data source: www.investing.com

ROE measures the overall profitability for the firm's owners and investors. It is a useful ratio that represents excess profits that remain after paying dividends, bonds and reinvesting in the business. Compared with ROA, ROE is a comprehensive ratio when compared with the industry average and historical ROE of the company. It can be seen that ROE of Apple and JD is higher than the industry level. Since ROE includes ROA and Leverage ratio, Apple and JD are more successful in generating profit internally. But the high ROE of Apple is attributed to the effect of leverage. From the data in Investing website, Apple has a debt to equity of $169.19 \%$ compared with the industry level of $53.27 \%$. JD has the debt to equity of $8.42 \%$ compared with the industry level of $56.46 \%$. High debt to equity ratio means apple may rely heavily on debt to generate a higher net profit, thereby boosting the ROE higher.

\subsection{Risk Analysis}

The risk analysis of three companies will be carried out from the two indicators of quick ratio and current ratio. Both current ratio and quick ratio are significant indicators to measure the short-term solvency of a company. In addition, the long-term debt-to-equity ratio is a measure of a company's ability to repay its long-term debt.

\subsubsection{Current ratio and quick ratio}

Table 3. Qualcomm's current ratio and cash ratio for 2017 to 2020

\begin{tabular}{|c|c|c|c|c|c|}
\hline Qualcomm & 2017 & 2018 & 2019 & 2020 & Industry \\
\hline $\begin{array}{c}\text { Current } \\
\text { ratio }\end{array}$ & 3.99 & 1.53 & 1.88 & 2.14 & 1.77 \\
\hline Quick ratio & 3.81 & 1.38 & 1.72 & 1.84 & 1.68 \\
\hline
\end{tabular}

Data source:

https://cn.investing.com/equities/qualcomm-inc-ratios

According to the data, the calculated current ratios for Qualcomm from 2017 to 2020 are $3.99,1.53,1.88$ and 
2.14, see table 2. Qualcomm's current ratios are relatively high on the whole but current ratios fluctuate too much. The latest data in 2020 shows that the current ratio of the whole industry is 1.77. The solvency of Qualcomm is higher than the level of the industry, so Qualcomm has a better operating condition. However, the ratios from 2017 to 2018 show a negative trend, because such a fluctuating current ratio indicates large changes in current assets and liabilities, which increases the risk of investment. In addition, a high current ratio is not a good thing either. A current ratio above 3 in 2017 indicates that current assets have not been effectively managed and used.

Qualcomm's quick ratios from 2017 to 2020 are 3.81, $1.38,1.72$ and 1.84, respectively, see table 3. Although the quick ratio changed a lot, the following four years showed a steady upward trend. It is higher than the industry quick ratio of 1.68 in 2021, indicating that Qualcomm has a strong ability to convert assets into cash, and the risk is less than the industry as a whole.

Table 4. JD's current ratio and cash ratio for 2017 to 2020

\begin{tabular}{|c|c|c|c|c|c|}
\hline JD & 2017 & 2018 & 2019 & 2020 & Industry \\
\hline Current ratio & 0.97 & 0.87 & 0.99 & 1.35 & 1.62 \\
\hline Quick ratio & 0.62 & 0.50 & 0.58 & 1.01 & 0.83 \\
\hline
\end{tabular}

Data source: https://cn.investing.com/equities/jd.cominc-adr-ratios

JD's current ratio and quick ratio both look low from 2017 to 2020 . The current rate remained stable at 0.97 , $0.87,0.99$ and 1.35 , respectively, see table 4 . Although the current ratio of JD is lower than the 1.62 of the whole industry, it shows a gradual upward trend. The quick rate of JD in the recent five years is $0.62,0.50,0.58$ and 1.01 . See table 2. Although the quick ratio seems very low, it is increasing every year and finally surpassed the industry average of 0.83 by 2020 . Due to the industry particularity of $\mathrm{JD}$, that is, inventory accounts for a large proportion, the quick ratio maybe can not better to measure the situation of JD. Even though, Investors can see that JD is becoming more and more solvent in the short term.

Table 5. Apple's current ratio and cash ratio for 2017 to 2020

\begin{tabular}{|c|c|c|c|c|c|}
\hline Apple & 2017 & 2018 & 2019 & 2020 & Industry \\
\hline $\begin{array}{c}\text { Current } \\
\text { ratio }\end{array}$ & 1.28 & 1.13 & 1.54 & 1.36 & 1.77 \\
\hline $\begin{array}{c}\text { Quick } \\
\text { ratio }\end{array}$ & 1.23 & 1.1 & 1.5 & 1.33 & 1.68 \\
\hline
\end{tabular}

Data source: https://cn.investing.com/equities/applecomputer-inc-ratios

According to the data, both Apple's cash ratio and its quick ratio declined annually from 2017 to 2018 and from
2019 to 2020, see Table 5. It is impossible to predict the future direction of cash ratios from four years' fluctuating data. In addition, for the past four years, both rates have been well below the average for the industry. Whether from the perspective of cash ratio or quick ratio, the short-term solvency of Apple is relatively low, and the investment risk is greater than that of the other two companies.

\subsubsection{Long-term debt-to-equity ratio}

The long-term debt-to-equity ratio is the capital structure in the balance sheet, which shows the degree of financial leverage and reflects the long-term solvency of an enterprise.

Table 6. Analysis of long-term debt-to-equity ratio

\begin{tabular}{|c|c|c|c|c|c|}
\hline $\begin{array}{c}\text { Debt-to- } \\
\text { equity ratio\% }\end{array}$ & 2017 & 2018 & 2019 & 2020 & Industry \\
\hline Qualcomm & 63.23 & 1906.07 & 273.94 & 252.46 & 46.96 \\
\hline JD & 20.99 & 16.52 & 12.27 & 6.68 & 53.8 \\
\hline Apple & 72.52 & 87.48 & 101.46 & 149.92 & 46,96 \\
\hline
\end{tabular}

Data source: www.investing.com

It can be observed from the data that the average debtto-equity ratio of the industry is about $50 \%$, while the debt-to-equity ratio of Qualcomm and Apple is much higher than this average. It shows that the proportion of long-term debt far exceeds equity, so the degree of protection for debt capital will be much weaker. Only JD's debt-to-equity ratio is much lower than the industry average, and it keeps declining year by year. This shows that JD Company has strong long-term debt repayment ability, and a high degree of guarantee for debt capital, so the investment risk is lower.

\subsection{Market Analysis}

In order to analyze the three companies the profit level of the common stocks, the sources of dividend distribution's sufficiency, the level of attraction to investors, the level of trust of investors, the existing risk and development potential and compare the situations in different industries, we choose three indexes -EPS, PE TTM and PB. We cannot find the PE-TTM of QUALCOMM in 2018-09-30 and that of JD in 2017-0930 as they were undisclosed. But the data at hand is enough to support the analysis of the problem.

\subsubsection{EPS}


Table 7. Three companies' EPS from 2017 to 2020

\begin{tabular}{|c|c|c|c|c|}
\hline $\begin{array}{c}\text { Company } \\
\text { Year }\end{array}$ & 2017 & 2018 & 2019 & 2020 \\
\hline Apple & $\$ 2.30$ & $\$ 2.98$ & $\$ 2.97$ & $\$ 3.28$ \\
\hline JD & $\$ 0.02$ & $\$ 0.26$ & $\$ 1.18$ & $\$ 4.86$ \\
\hline
\end{tabular}

Data Source: https://www.macrotrends.net/.

According to the data in Table 7 , we can see that the annual EPS of QUALCOMM kept around \$4 in 2019 and2020. However, the figures in 2017 and 2018 seemed much lower. The annual EPS in 2020 was approximately $\$ 4.52$, which means common stock holders can be entitled to the net profit of $\$ 4.52$ per share. Compared to that in 2019 , it increased by nearly $25.91 \%$. Therefore we can see that the profit level of the common stocks improved and the sources of dividend distribution became more sufficient. More attention would be paid by the investors to the stock market.

Overall, the figure of Apple rose steadily .The annual EPS reached $\$ 3.28$ in 2020, which implies the net profit per share increased by $10.44 \%$.

It means the common stock holders can be entitled to more net profits and the company's profitability became higher, which can attract more investors' attention.

We can get the information that JD' $s$ annual EPS revealed negative from 2017 to 2018, which means it had been losing money for a long time. The situation seemed not so positive in early times, but it still existed for a long time. It finally gained profits in 2019 and the EPS rose obviously in 2020. During the period from 2017 to 2020, the loss had declined in general.

In the whole, the sources of dividend distribution became more sufficient and the profitability of the company improved.

Through comparison, we can discover JD' s EPS was the lowest in general among these three companies, which was negative in the first two years and but the figure had shown an upward trend since 2019.

\subsubsection{PE-TTM}

Table 8. Three companies' PE-TTM from 2017 to 2020

\begin{tabular}{|c|c|c|c|c|}
\hline Time & $\begin{array}{c}\text { 2017-9- } \\
30\end{array}$ & $\begin{array}{c}\text { 2018-9- } \\
30\end{array}$ & $\begin{array}{c}\text { 2019-9- } \\
30\end{array}$ & $\begin{array}{c}\text { 2020-9- } \\
30\end{array}$ \\
\hline Qualcomm & 28.07 & & 20.74 & 25.74 \\
\hline Apple & 16.04 & 18.48 & 18.65 & 35.41 \\
\hline JD & & 186.36 & 76.24 & 29.62 \\
\hline
\end{tabular}

Data Source: https://www.macrotrends.net/.

According to the data in Table 8, we can see the TTM PE ratio of QUALCOMM experienced a significant increase from 2019-09-30 to 2020-09-30. Besides, every year's PE ratio was beyond 20.

It means the value of the company was overestimated [23]. It implies the trust from investors. As a company of wireless communications technology and chip development, it has plenty of scope for development with its own excellent quality and the constant development of communication technology.

We can see that there was a growing trend in Apple's TTM PE ratio from 2017-09-30 to 2020-09-30.

The figures for 2017-09-30,2018-09-30 and 2019-0930 were larger than 14 but smaller than 20, which implies that the value of the company may be at a normal level [23]. After that, the PE ratio grew sharply and reached 35.41 overtaking 21 . It means investors were will to pay 35.41 for each unit of revenue or profit the company makes. At this time, the value might be overestimated, which reflects the recognition of the investors [23]. In other words, they believe Apple has development potential. But they need to take a high risk for their own belief since the future is uncertain and the ratio which was higher than 28 might reflect there was a speculative bubble in the stock market [23].

According to the data in the chart, we can find that the PE ratio of JD was very high which was beyond 28 from 2018-09-30 to 2020-09-30.

It means it was overestimated to a large degree but it may also imply that there was a speculative bubble in the stock market [23].

In general, JD had the highest PE-TTM which overtook the figures for the other two companies a lot especially in 2018-09-30 and 2019-09-30. 


\subsection{3. $P B$}

Table 9. Three companies' PB from 2017 to 2020

\begin{tabular}{|c|c|c|c|c|}
\hline & $2017-$ & $2018-$ & $2019-$ & $2020-$ \\
& $12-31$ & $12-31$ & $12-31$ & $12-31$ \\
\hline QUAme & & & & \\
\hline Apple & 5.89 & 6.17 & 14.24 & 33.66 \\
\hline JD & 7.34 & 3.42 & 4.24 & 4.35 \\
\hline
\end{tabular}

Data Source: https://www.macrotrends.net/.

According to Table 9, from 2017 to 2021, the figure for QUALCOMM increased sharply in 2018 and remained stable later.

The ratio of QUALCOMM was higher than 3 in general, which means it sets up a better company image [24]. The market price was much higher than the book value and showed the firm was well-capitalized revealed a good development potential.

There was a significant growth trend in the ratio of Apple during the period from 2017 to 2020.

We can see that the figure rose year by year, which implies the company's image improved constantly these years. Apple relied on its own technical advantage, advanced management model and its broad market winning trust of more and more consumers and investors. The increase of this ratio also revealed its huge development potential in the future.

Compared to the two companies above, the ratio of JD is not very high, but it overtook 3 , which means it also had a good company image in the market [24]. However, we can see it experienced a decline in 2018.

But overall, its development potential was good in the future with its own cash flow model and the increasing number of users in the market.

Overall, JD had the highest PE-TTM but its PB was the lowest. The annual EPS of JD was the smallest.

JD's EPS was the lowest in general compared with another two companies, which means its source of dividend distribution was not very sufficient and the profit level of the common stocks was not very high. Besides, its PB was also the lowest among the three. Although the ratio of JD is not very high, it overtook 3, which means it also had a good company image in the market [24]. It is surprising that its PE-TTM was the highest in the whole. We can find that the figure was very high which was generally beyond 28 , which means it was overestimated to a large degree. In other words, quite a lot of investors trusted this company and regarded the prospects of the company favorably. There would be two main reasons for this. The first is the high cash flow. The company chose "B2C" cash flow model which make itself have access to sufficient cash flow. Under this model, they do not need to dare capital chain rupture. The other one is the recognition of the market. As a large ecommerce platform in China, it has already gained the consumers' and investors' trust which brought much investment to the firm supporting its development [25]. And the large increasing number of users played a significant role in the later profits in 2019 [26]. It stands for the growth potential of JD to a large degree. But due to the extremely high ratio, we should consider the risk speculative bubble in the stock market may bring.

\section{CONCLUSION}

From the theoretical perspective of value investment, this paper conducts index analysis on three enterprises: Jingdong, Qualcomm, and Apple. Through the analysis of risk, profit, and market, we draw a conclusion. In terms of profitability, we analyze that although JD's return on assets is not high, it does not need expensive real estate and equipment to generate income like Qualcomm and Apple. And in terms of return on equity, JD has performed well, not relying on debt to generate net profit like Apple. In terms of risks, we analyze that Apple has high debt and weak debt repayment ability, while Qualcomm has low short-term debt repayment risk, but its capital operation and long-term debt repayment ability are not as good as JD. In terms of the market, we analyze that Jingdong has a good image in the market, attracted a lot of investment, and is a company favored by the public.

According to the research conclusions of this paper, we put forward the following suggestions. From the company's perspective, we can know to increase the market price can not only bring more capital gains but also make PE -TTM higher which may transmit a positive signal to investors in the market. To improve market price, the most effective way is to make efforts to achieve a good performance. At the same time, enterprises should also understand the importance of debt management. Not only should enterprises use debt management to obtain financial leverage benefits, but need to avoid financing risk, and make debt financial plans to maintain a reasonable debt ratio. Only when an enterprise manages itself well can it attract more high-quality investors. The company is supposed to maintain the ROE to a better level so that company may generate more capital from investors. Notice that ROE includes the effect of leverage. To improve ROE, the company can finance by debt to reduce the reliance on equity. However, if the company borrows aggressively, the cost of debt will decrease net income. Financial leverage will increase ROE if the company controls the cost of debt. From a country perspective, the government should introduce tax-reduced policies, which have a positive influence on 
the operating environment of companies. It allows entrepreneurs to save money from taxes and invest more in profitable projects.

Besides, the government put forward policies which guide institutions and even individual investors to accept and adhere to the concept of value investment, support the long-term development of excellent companies with a long-term vision, and reduce market price fluctuations. Optimize the listing system and select the target for expansion is also important. It helps in providing a stock market with a more value-creating company for value investment. Strengthen the guidance of long-term capital to enter the market. From the perspective of the development history of mature markets, long-term funds, especially pension funds, are the guarantee for the longterm healthy development of the capital market. Countries can speed up the improvement of the pension system, improve the tax incentive system of the enterprise annuity system, and encourage residents to participate in the pension system so that more pension funds enter the market. From the perspective of individual investors, investors need to understand the company's profitability through ROA and ROE, understand the company's image in the market, and determine the risk of investment through short-term and long-term repayment indicators. Investment selection should be made after careful analysis of the company's value according to its own conditions and conditions.

This paper puts forward three key indicators, namely profit index, risk index, and market index, to evaluate the investment value of enterprises. It provides basic investment guidance for enterprises and individuals who lack investment experience. Based on the limited data and information, this paper evaluates the investment value of listed companies through financial indicators. There are some non-financial indicators to be considered and studied in the later stage.

\section{REFERENCES}

[1] Li, L., Li, J. (2020). Firm Valuation and Value Growth [M]. Democracy and Construction Press.

[2] Zhang, M. (2020). Investment Value Analysis of Listed Companies in China's IC Industry [D]. Anhui University of Finance and Economics.

[3] Zou, X. (2020). Research on the investment value of industrial automation boss company [C]. Zhejiang University

[4] Wang, G. (2009). Preparing for the GEM valuation method is the key. Journal of China asset valuation, 07, 11-15.

[5] Graham, B., Dodd, D. L. F., \& Cottle, S. (1934). Security analysis (pp. 44-45). New York: McGraw-Hill.
[6] Gray, W.R. and Carlisle, T.E. (2013), Quantitative Value: A Practitioner's Guide to Automating. Intelligent Investment and Eliminating Behavioral Errors, Wiley Finance, Hoboken, NJ.

[7] Basu, S. (1977), Investment performance of common stock in relation to their price-earnings ratio: a test of efficient market hypothesis, Journal of Finance, Vol. 32 No. 3, pp. 663-682.

[8] Oppenheimer, H. (1984), A test of ben Graham's selection criteria, Financial Analyst Journal, Vol. 40 No. 5, pp. 68-74.

[9] Stephen, P., Francesco, R. (2018) Fundamentals of Value versus Growth Investing and an Explanation for the Value Trap. Financial Analysts Journal 74:4, pages 103-119.

[10] Lev, B. (2019). Explaining the Recent Failure of Value Investing by Baruch Lev, Anup Srivastava :: SSRN.

SSRN. https://papers.ssrn.com/sol3/papers.cfm?abstract_id $=3442539$

[11] Israel, R. (2020). Is (Systematic) Value Investing Dead? The Journal of Portfolio Management. https://jpm.pm-research.com/content/47/2/38

[12] Information from www.investing.com

[13] Information from www.macrotrends.com

[14] Information from www.readyratios.com

[15] Ross, S. A., Westerfield, R., \& Jordan, B. D. (2008). Fundamentals of corporate finance. Tata McGraw-Hill Education.

[16] Zhang Baoqing. (2019). Discussion on current Ratio Index. Journal of Shandong Economic Management Cadre Institute, 04, 36-37.

[17] Hui, R. (2018). Research on Analysis Indicators of Solvency of Enterprises. Journal of Shopping Mall Modernization, 18,117-118.

[18] Cai, M., \& Wang, L. (2019). Research on EPS of Kweichow Moutai. Journal of Jilin Engineering Normal University, 035(008), 83-85.

[19] Liu, Y. (2018). A Brief Talk About the Factors Affecting the Price Earnings Ratio and the Current Situational Development of China's Stock market Price Earnings Ratio. Era of economic and trade, No.439(14), 21-22.

[20]Information from https://wiki.mbalib.com/wiki/TTM

[21] Information from http://wm8pc.cn/WiOIp 
[22] Lu, J., \& Liao, G., (2002). The Comparison of PE Ratio,PB,Free Cash Flow Multiplier and Portfolio Return. Economic Management, 000(014), 57-62.

[23] HALL, A.D. (2003). Introduction to Stock Investment. China Financial Publishing House.

[24] Information from http://ssnew.cn/QjQ20

[25] Information from http://ndctf.com/Yr1Xl

[26] Information from http://ndctf.com/jirp5 